\title{
Economics of the Scholarly Journal
}

\author{
David W. Lewis
}

This paper considers the economic nature of the scholarly journal from a theoretical perspective and concludes that it is what economists call a natural monopoly. Natural monopolies exist when the average price of the good falls over the range of demand, and unless a subsidy is provided the good will not be produced in the quantity that provides the most social benefit. The natural monopoly model of the scholarly journal sheds light on the issue of dual pricing and explains how scholarly publishing can be a highly profitable enterprise. Because subsidies should be easier to implement in electronic systems, this alternative may provide a more effective means of scholarly communication.

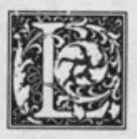

ibrarians and the publishers of scholarly journals have a long: history of disagreement over prices. Librarians feel exploited, and publishers misunderstood. Neither side seems to be able to see the other's point of view. ${ }^{1}$ This lack of comprehension occurs, at least in part, because librarians are not knowledgeable about the economics of scholarly journal publishing. If librarians are to make reasoned and reasonable policy decisions on the distribution of scholarly information, the situation must change. The scholarly journal is only one means of distributing scholarship, but if we understand its economics, we can apply our insights across the board. This article will explore the economics of the scholarly journal and along the way will consider dual pricing and the changes electronic systems may bring.

We will begin by examining the scholarly journal's production characteristics and the nature of the scholarly journal's demand as a product in the marketplace. To do so, we will use a simple example to explore these characteristics and the interplay that results among libraries, scholars and publishers. As is the case whenever simple models are used to portray a complex reality, some of the detail and texture will be lost, but in compensation we will be given the opportunity to see clearly relationships that might otherwise elude us.

\section{SUPPLY}

Different goods are made in different ways. To describe the differences, economists develop production functions that explain how, for the particular product, inputs are turned into outputs. The production function for scholarly journals is twofold. There is a large, up-front fixed cost-what publishers call the "first copy cost." This expenditure is necessary to select and edit articles, to lay out pages, and to maintain subscription lists and a distribution system. It must be paid regardless of how many copies of the journal are sold. The cost of printing and distributing each unit after these setup costs have been paid is relatively small. Let us assume for our example that the fixed costs for a year of production of a hypothetical journal are $\$ 10,000$ and that the per-unit costs are $\$ 10$ per subscription. The total cost of produc-

David W. Lewis is Head, Research and Information Services at the Homer Babbidge Library, University of Connecticut, Storrs, Connecticut 06268. 
ing between 10 and 1,000 units of this journal are shown in table 1 . Also shown are the average cost-the total cost divided by the number of subscriptions-and the marginal cost. The marginal cost is the additional cost of producing one more unit of output; in our example, the marginal cost is for printing and distribution and is always $\$ 10$. The same information is shown graphically in figure 1 . Note that the average cost drops rapidly as the volume of production increases; the more units produced, the closer we come to the relatively low marginal cost. But the average cost never falls below the marginal cost. The importance of this attribute of the production function will become clear shortly.

\section{DEMAND}

Scholarly journals have two markets, libraries and individuals. These markets differ in important ways. Libraries are generally willing to pay more than individuals for journals. They are also less likely to place or cancel their subscriptions because of changes in prices, and price, although a consideration, is rarely the primary factor in determining whether to purchase a title. Usually a library will decide which journals are important and purchase as many of them as it can afford. Once a subscription has been placed it is usually continued without serious review unless there is a fiscal crisis. When prices rise libraries will cancel a subscription only hesitantly, even when this means buying fewer books or making other budget cuts. For libraries, price changes have relatively little effect on purchasing behavior. ${ }^{2}$ In the language of economics, library demand for scholarly journals is inelastic. An often-cited textbook example of inelastic demand is kidney dialysis. Libraries, like the kidney patient, may complain about prices, but they pay them nonetheless.

Another important aspect of library demand is the limited substitutability between scholarly journals. Foreign Affairs, Orbis, and Foreign Policy are all important journals covering international relations, but a library will rarely substitute one for the other solely on the basis of price. From the library's point of view, these three ti- tles are different goods. Importantly, this implies that in the library market scholarly journals are monopoly goods and publishers have monopoly power. As Edward Dyl deftly points out, all publishers of copyrighted works are monopolists. ${ }^{3}$ This view is, however, simplistic. The titles noted are distinct goods not because they are copyrighted, but because academic library users, especially faculty members, who have much to say in these matters, will not generally accept an article from Orbis when what they seek is an article from Foreign Affairs. This point is critical. One can argue as Malcolm Getz has that "the possibility of new titles by other publishers entering the journal marketplace defines an upper limit on journal prices. ${ }^{\prime 4}$ New scholarly journals do enter the market and in some cases they replace other scholarly journals. But it is my contention that the general case is more like the one that Getz goes on to describe: "To the extent that a particular title achieves a distinctive editorial position and reputation for important essays .... new entrants may pose little threat." ${ }^{\prime 5}$ Sandra Moline found a large variance in journal prices, even when the number of characters published was considered. ${ }^{6}$ These findings, which at first may seen puzzling, are easily understood when scholarly journals are seen as monopoly goods. The important point is that for scholarly journals, reputation and distinctive editorial position, once gained, are lost very slowly. It is this fact that makes them distinct goods and provides their publishers with monopoly power.

Popular journals are different. For example, a library might decide to subscribe to one magazine about Macintosh computers; it could be MacUser, MacWeek, or MACazine. Price will probably be an important factor, and should the chosen title suddenly double in price, there would be little hesitancy in canceling that title and subscribing to a cheaper one. Here there is substitution, even of copyrighted material, and elastic demand. What results is a more competitive market that relies on advertising to help finance publication.

Individuals, at least in part because libraries provide them with an alternative 


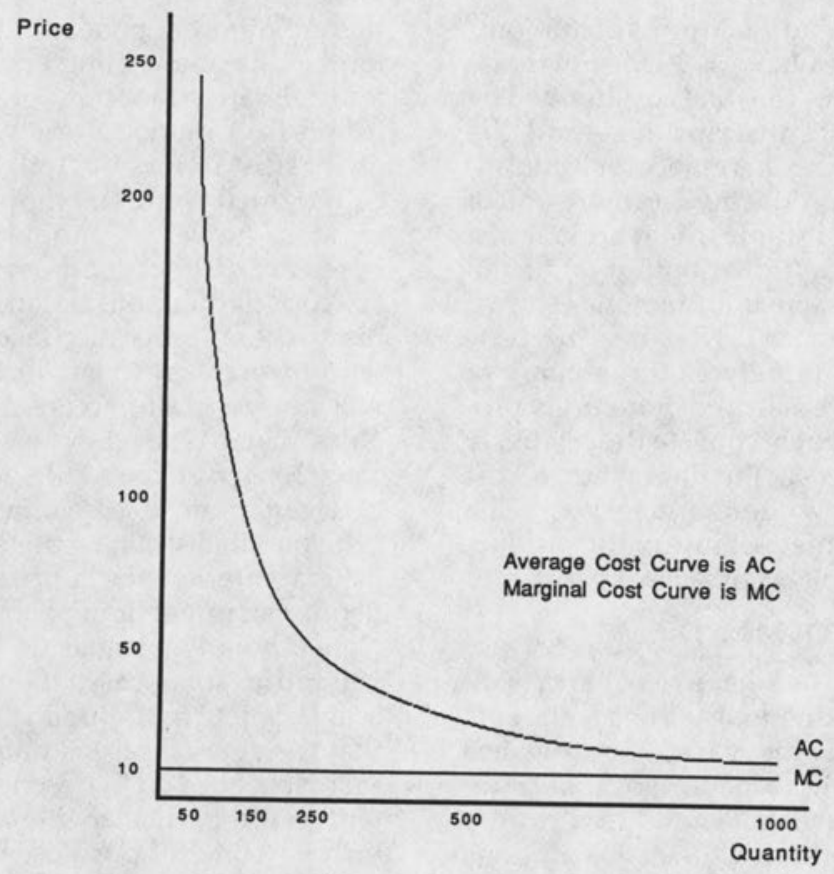

FIGURE 1

Cost Curves

to ownership, have lower limits of the top price they are willing to pay for a journal; they are more likely to adjust their purchases when prices change. Individual demand for scholarly journals is more elastic than the library demand.

For the sake of our example, let us assume that in the library market there are 250 possible subscribers and the most any of them is willing to pay for our journal is $\$ 250$ per year. To make things easy we will assume that the demand is linear function. The equation for this function will be

\section{quantity purchased by libraries =} 250 - price charged libraries

This is the function that describes the line $\mathrm{ABC}$ in figure 2 . If we similarly assume that there are 750 possible individual subscribers and that the most any one of them would be willing to pay is $\$ 25$ per year, and that once again the demand is a linear function, personal demand could be represented by the function quantity purchased by individuals = 750 - (30 $\times$ price charged individuals)

This is the equation for line DE in figure 2. If we combine the two demand curves to find the demand for the total market, we will have a curve that is linear but that has an elbow. Above a price of $\$ 25$, the curve is the library demand curve since above $\$ 25$ no individuals will purchase the journal. Below $\$ 25$, the library and personal demand curves must be added together. The combined demand function is

if price is greater than $\$ 25$, then quantity purchased $=250$ - price

if price is less than or equal to $\$ 25$, then quantity purchased $=1,000-(31 \times$ price $)$ This is the equation for line $\mathrm{ABF}$ in figure 2.

\section{SUPPLY AND DEMAND}

When we bring together the supply and demand curves, we can begin to understand the nature of the scholarly journal 


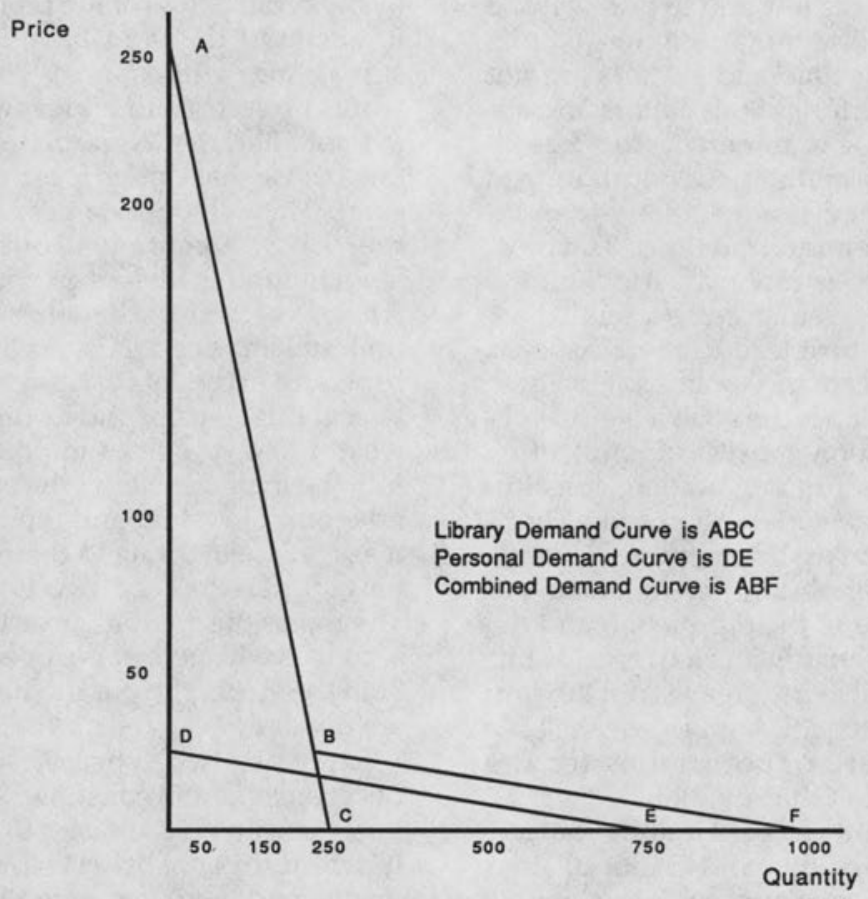

FIGURE 2

Demand Curves

market. This is shown in figure 3. In a competitive market, an equilibrium is established at the point where the marginal cost curve intersects the demand curve. At this point, the cost of production will be equal to the willingness of the consumer to pay. This results in marginal cost pricing. The amount produced at this point is the efficient quantity and the price charged is the efficient price. Production at this point and at this price provides the greatest benefit to society. In our example, with a marginal cost of $\$ 10$, the demand will be 690 subscriptions. There is, however, a problem. At this point the revenue from selling 690 subscriptions will be $\$ 6,900-\$ 10$ per subscription times the 690 subscribers. The cost of producing this number of subscriptions will be $\$ 16,900-$ the $\$ 10,000$ fixed costs and the $\$ 10$ variable cost times 690 . There will be a loss to the publisher of $\$ 10,000$.

Economists call this situation a natural monopoly. A natural monopoly occurs when the average cost falls over the entire range of demand; it is a common occurrence where there are large up-front costs, low per-unit costs, and limited substitutability. This is the case for scholarly journals. An important implication of a natural monopoly is that, without a subsidy, no for-profit firm will undertake the publication of the journal and price it at marginal cost. In fact, even if a price above marginal price is charged, there will be a loss. For example, if the subscription price were $\$ 20$, there would be 380 subscriptions, revenues of $\$ 7,600$, costs of $\$ 13,800$, and a loss of $\$ 6,200$. A profit can be made, but only at a price where the average cost curve is above the demand curve. In our example this break-even point is a subscription price of $\$ 64$ and 186 subscribers. This is a long way from the efficient price and the efficient quantity.

The fact that scholarly journals are natural monopolies explains a great deal. We see why there is a strong incentive to keep 
the up-front costs low and to find ways to subsidize publication. To do this, editors volunteer their time and authors are not paid for their efforts. Both editors and authors are willing to undertake this free labor because, in addition to contributing to knowledge, they assume a long-term increase in academic reputations. The pressure to keep costs low may also limit the number of pages that can be published, which may in turn lead to more rigorous review and acceptance policies. Finally, if wide distribution is the goal, a way to subsidize publication must be found; often support comes from an academic institution or scholarly society. If not, the shortfall can be made up by accepting advertising. What is important to understand is that the nature of the production and the demand for scholarly journals creates this situation. Publishers' greed is not the fundamental cause, although as we shall see later, there are opportunities for the greedy to exploit the situation.

It is important to avoid another fallacy. Inelastic library demand is not all that causes high journal prices; it is the interaction of this demand function with the production function of the scholarly journal. Even if libraries somehow managed to change the nature of their demand so that it was more elastic, scholarly journal prices would not come down; rather, journals would go out of business. Because scholarly journals are natural monopolies, they require subsidies if they are to produce at the efficient quantity. ${ }^{8}$ Without the inelastic library market, they would not be published at all. The important and difficult question is how best to provide the required subsidy.

\section{SURPLUS AS A MEASURE OF SOCIAL BENEFIT}

Before going on, we need to better understand natural monopolies. One might suspect that natural monopolies, which price at marginal cost, would be rare because no profit can be made. Why would we want or even accept a price and production level at the efficient quantity? Why would we want a venture that always operates at a loss? The answer is simple: not all the benefit gained is measured by the profit or loss of the producer. We all understand this and have little trouble supporting, with our tax dollars, public works projects from bridges and subways to public libraries. None of these ventures, even those that charge fees or tolls, breaks even. They all operate year after year in the red with continued public support. Even though there is no profit, society as a whole is better off when these projects are undertaken. Economists call the societal benefit in excess of cost, surplus. A closer look at this concept and its flip side, deadweight loss, provides important insights into the inefficiencies of the current scholarly journal system and the policy dilemmas we face in trying to change it. It is important here to keep two issues distinct. The first is the amount of surplus, and the second is who gets it. We need to consider both the size of the pie and how the pieces are divided.

There are two types of surplus, producer surplus and consumer surplus. Producer surplus is the easier to understand. It is the difference between the cost of producing and the revenue received; it is the producer's economic profit or loss. ${ }^{9}$ In our example, at marginal cost pricing the producer surplus is negative. Consumer surplus is less clear-cut. It is the difference between the demand curve and the consumer's cost for the product. One way to think about this is to consider the one library subscriber who is willing to pay $\$ 250$ for our sample journal and assume that this $\$ 250$ is reflective of the value this journal has to the library. But because the price is based on marginal cost, the library is only charged $\$ 10$. The difference, $\$ 240$, is the measure of benefit the library receives but for which it does not pay. If we look at all the consumers who place a value on the journal above the price they are charged, we have the total consumer surplus. In our example, at marginal cost pricing, this is the shaded area in figure 4 . By comparing figure 3 and figure 4 , it should be clear that the negative producer surplus of $\$ 10,000$ is offset by a larger consumer surplus. This surplus turns out to be $\$ 32,175$. In our example, even though there is a loss to the publisher, society as a whole benefits. The measure of this benefit is the total 


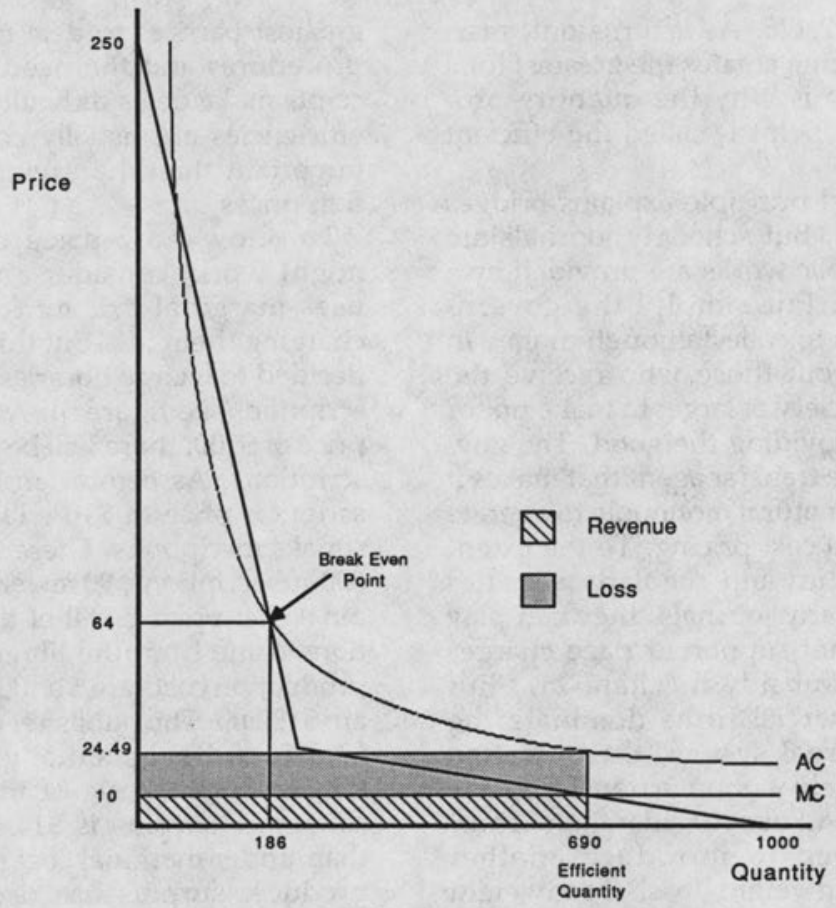

FIGURE 3

Natural Monopoly Marginal Cost Pricing

Price

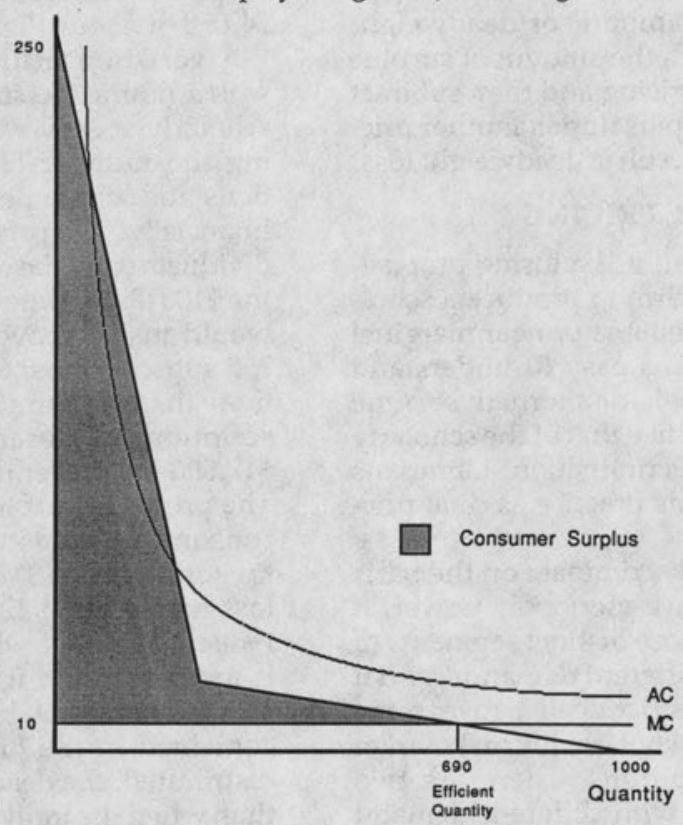

FIGURE 4

Consumer Surplus with Price at Margin Cost 
surplus of $\$ 22,175$. As it turns out, marginal cost pricing creates the greatest total surplus. This is why the quantity produced at this point is called the efficient quantity.

This general principle explains bridges and subways. But scholarly journals are different. Public works are provided by a government. Put simply, the government's role is to collect enough money in tax dollars from those who receive the benefit, or society at large, to make up for the loss in providing the good. The government is the transfer agent that makes it possible for a natural monopoly to operate with marginal cost pricing. To the extent that universities and scholarly societies publish scholarly journals, they can play this role. Grant-supported page charges are another subsidy mechanism. ${ }^{10}$ But where commercial firms dominate the scholarly journal system, the operation functions largely without a transfer agent.

Before we end our consideration of surplus, we need to introduce another concept-deadweight loss. Deadweight loss is the measure of lost societal benefit, that is, of how much the pie has shrunk. To calculate the amount of deadweight loss, we begin with the amount of surplus at marginal cost pricing and then subtract the amount of surplus under another pricing scheme. The result is deadweight loss.

\section{DUAL PRICING}

As we have seen, it is a losing proposition for a private firm to produce a scholarly journal and sell it at or near marginal cost. Therefore, it is easy to understand why publishers look for alternatives. One option in a market like that of the scholarly journal is price discrimination. Librarians usually refer to this practice as dual pricing.

Producers can discriminate on the basis of price if they have monopoly power, if there are two or more distinct segments of the market with different demands, and if it is possible to restrict deals between the two groups. The scholarly journal market meets these conditions. There are two market segments with different demand functions and resale deals are limited. Ironically, it is libraries that create the greatest barriers to deal making. Library procedures and the need for reliable receipts make deals difficult, and operating efficiencies are usually considered more important than the savings on subscription prices.

To show how price discrimination might work, consider a publisher who uses marginal pricing for individuals, charging them $\$ 10$. But this publisher has decided to charge libraries $\$ 100$ for a subscription (see figure 5). At a subscription price of $\$ 100$, there will be 150 library subscriptions. As before, an individual subscription price of $\$ 10$ will bring 450 personal subsciptions. There will be a total of 600 subscriptions, 90 fewer than with marginal cost pricing. All of the lost subcriptions come from the library market. The production costs are $\$ 16,000$ and revenues are $\$ 19,500$. The publisher earns a profit of $\$ 3,500$ and substantially improves the long-term prospects of the journal. The consumer surplus is $\$ 14,625$, much less than under marginal cost pricing, but the producer surplus has risen by $\$ 13,500$, from negative $\$ 10,000$ to $\$ 3,500$. The total surplus is $\$ 18,125$, and deadweight loss is $\$ 4,050$ or about 18 percent.

A variation of this pricing scheme is worth noting. Assume the publisher is a scholarly society with a goal of maximizing the number of individual subscriptions and with a need only to break even financially. The price of the journal for individuals could be cut in half, to $\$ 5$, and if the $\$ 100$ library rate was maintained, costs would just be covered. There would be 750 subscriptions: 600 to individuals, 150 more than with the $\$ 10$ price, and 150 subscriptions to libraries. Costs would be $\$ 17,500$ and revenues would be $\$ 18,000$. The producer surplus would be $\$ 500$. The consumer surplus would be $\$ 17,250$ and the total surplus $\$ 17,750$. The deadweight loss would be $\$ 4,425$. This situation is interesting because while consumer surplus is increased, and it might be argued that society is better off because the knowledge contained in the journal is more widely distributed, the deadweight loss is greater than when the individual price is set at $\$ 10$ and there are 150 fewer individual subscribers. 


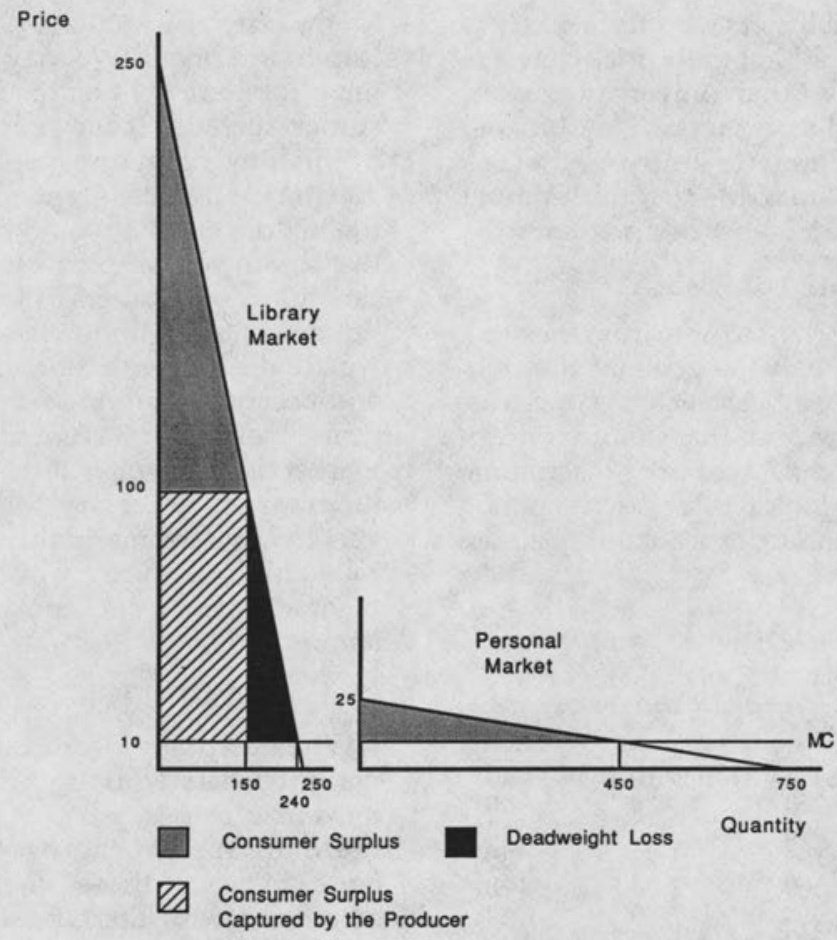

FIGURE 5

Dual Pricing

If, on the other hand, the goal of the publisher is to maximize profits, prices would be set differently. A monopolist seeking to maximize profit will produce the quantity where the marginal revenue equals marginal cost. That is, where the costs of producing the last item is equal to the revenue earned on the last sale. If this is done in the two markets, the library price would be set at $\$ 135$, which would bring 115 library subscriptions. The individual subscription price would be set at $\$ 22.50$ and there would be 75 individual subscribers. ${ }^{11}$ There would be a total of 190 subscriptions; cost would be $\$ 11,900$ and revenues would be $\$ 17,212.50$. The publisher would realize an economic profit of $\$ 5,312.50$, which is also the producer surplus. The consumer surplus would be $\$ 7,893.75$ for a total surplus of $\$ 13,206.25$. There would be a deadweight loss of $\$ 8,968$, a full 40 percent. From the point of view of the consumer and of society at large, this is the worst case we have yet considered, but it is the best for the publisher. ${ }^{12}$ The alternative pricing strategies, the quantities produced in the two markets, and the profits that result are shown in table 2. Table 3 shows the surplus generated in each case.

If we take a broad view of the process of scholarly communication, we might find the first two examples of price discrimination acceptable. Libraries subsidize individuals, but the result is a widely distributed journal that has the wherewithall to continue on sound financial footing. ${ }^{13}$ In the latter case, we would probably react differently. Again libraries provide the means to make the journal successful, but this time, rather than achieving the broad distribution of scholarship, only a few can afford to subscribe. The benefit of the enterprise goes to the publisher, not to the academic community. There are indications that both strategies are used by scholarly journal publishers. Dyl's study of business and economics journals found 
that private publishers were more likely to discriminate and that their price differentials were greater than university presses' or professional associations'. ${ }^{14} \mathrm{~A}$ broader and more systematic study by Patrick Joyce and Thomas Merz found similar results across a number of disciplines. ${ }^{15}$

\section{THE DILEMMA}

What is important to note from these examples is that it is the goals of the publisher and the way in which the price discrimination is applied that should concern us, not simply the fact of price discrimination. When we look at price discrimination we must be clear about what our goals are

TABLE 1

PRODUCTION COSTS

\begin{tabular}{cccc}
\hline \hline $\begin{array}{c}\text { Units } \\
\text { Produced }\end{array}$ & $\begin{array}{c}\text { Total } \\
\text { Cost (\$) }\end{array}$ & $\begin{array}{c}\text { Average } \\
\text { Cost (\$) }\end{array}$ & $\begin{array}{c}\text { Marginal } \\
\text { Cost (\$) }\end{array}$ \\
\hline 10 & 10,100 & 1,010 & 10 \\
25 & 10,250 & 410 & 10 \\
50 & 10,500 & 210 & 10 \\
150 & 11,500 & 77 & 10 \\
250 & 12,500 & 50 & 10 \\
500 & 15,000 & 30 & 10 \\
1,000 & 20,000 & 20 & 10 \\
\hline
\end{tabular}

for the scholarly journal system before we leap to judgment. We may wish to maximize total surplus or to maximize consumer surplus. If we hold stock in the publishing company, we may wish to maximize producer surplus. A position on the middle ground would be to maximize the amount of surplus that at the same time allows publishers to stay in business. We need also to understand that because we are dealing with a natural monopoly, and because many producers are private firms, we cannot have it all at once. The market does not have the means to make the transfers necessary both to maximize surplus and to maintain viable private publishing ventures. This is the fundamental cause of the scholarly journal dilemma.

\section{X-INEFFICIENCY}

While there are clear examples of journal publishers who are in the market to maximize profits, it is equally clear that there are many who have more noble ends. But even those who are primarily concerned with the wide distribution of scholarly information are affected by mar-

TABLE 2

PRICING STRATEGIES, SUBSCRIPTION LEVELS, AND RESULTING PROFITS

\begin{tabular}{lrrrr}
\hline \hline & $\begin{array}{c}\text { Marginal } \\
\text { Cost } \\
\text { Price }\end{array}$ & $\begin{array}{c}\text { Dual } \\
\text { Price } \\
\text { One }\end{array}$ & $\begin{array}{c}\text { Dual } \\
\text { Price } \\
\text { Two }\end{array}$ & $\begin{array}{r}\text { Dual } \\
\text { Price } \\
\text { Three }\end{array}$ \\
\hline Cost to libraries & $\$ 10$ & $\$ 100$ & $\$ 100$ & $\$ 135$ \\
No. of library subscriptions & 240 & 150 & 150 & 115 \\
Revenue from libraries & $\$ 2,400$ & $\$ 15,000$ & $\$ 15,000$ & $\$ 15,525$ \\
Cost to individuals & $\$ 10$ & $\$ 10$ & $\$ 5$ & $\$ 22.50$ \\
No. of individual subscriptions & 450 & 450 & 600 & 75 \\
Revenue from individuals & $\$ 4,500$ & $\$ 4,500$ & $\$ 3,000$ & $\$ 1,687.50$ \\
Total subscriptions & 690 & 600 & 750 & 190 \\
Total revenue & $\$ 6,900$ & $\$ 19,500$ & $\$ 18,000$ & $\$ 17,212.50$ \\
Total costs & $\$ 16,900$ & $\$ 16,000$ & $\$ 17,500$ & $\$ 11,900$ \\
Profit & $\$ 10,000$ & $\$ 3,500$ & $\$ 500$ & $\$ 5,312.50$ \\
\hline
\end{tabular}

TABLE 3

PRICING STRATEGIES AND RESULTING SURPLUS

\begin{tabular}{lcccr}
\hline \hline & Marginal & Dual & Dual & Post \\
& Price & Price & Price & Dual \\
Price & Three \\
\hline Consumer surplus & $\$ 32,175$ & $\$ 14,625$ & $\$ 17,250$ & $\$ 7,893.75$ \\
Producer surplus & $-\$ 10,000$ & $\$ 3,500$ & $\$ 500$ & $\$ 5,312.50$ \\
Total surplus & $\$ 22,175$ & $\$ 18,125$ & $\$ 17,750$ & $\$ 13,206.25$ \\
Deadweight loss & - & $\$ 4,050$ & $\$ 4,425$ & $\$ 8,968.75$ \\
\% of deadweight loss & - & $18 \%$ & $20 \%$ & $40 \%$ \\
\hline
\end{tabular}


ket conditions. In exploring how this is so, it is useful to employ the economic concept of $x$-inefficency. X-inefficiency results when a product is produced at greater than least possible cost. This occurs when a firm has monopoly power and in the usual example is caused by managers who give themselves unnecessary perquisites such as expensive lunches or mahogany desks in corner offices. As we have already noted, scholarly journals, at least in the library market, have considerable monopoly power, but as we have noted, most scholarly editors and authors work for little or no pay. Where then are the unnecessary perquisites? We must look more closely at the goals of scholarly publishing.

One purpose of the scholarly journal is the distribution of scholarly information and, through libraries, the creation of an archive of the cumulative knowledge of humankind. But there is a second and, to many, more important purpose. As we briefly noted previously, publishing is one of the primary means by which scholars achieve the recognition of their peers. This recognition in turn brings promotion, tenure, and financial reward. It is this latter purpose that provides the incentive for $\mathrm{x}$ inefficiency.

There is no question that scholars are pressured to publish, nor is there much doubt that a sizable proportion of this publication is redundant or of less than outstanding quality. Many decry the situation, but it continues and, if anything, grows worse. How can this be given refereeing systems and peer review? The answer is simple. The same inelastic demand for scholarly journals in the library market that can allow a profit-maximizing publisher to reap large profits allows an editor who wishes to maximize the number of papers published in his or her journal to do so. Profits do not go to the bank; rather they are used to increase the size of the journal. The larger journal provides more
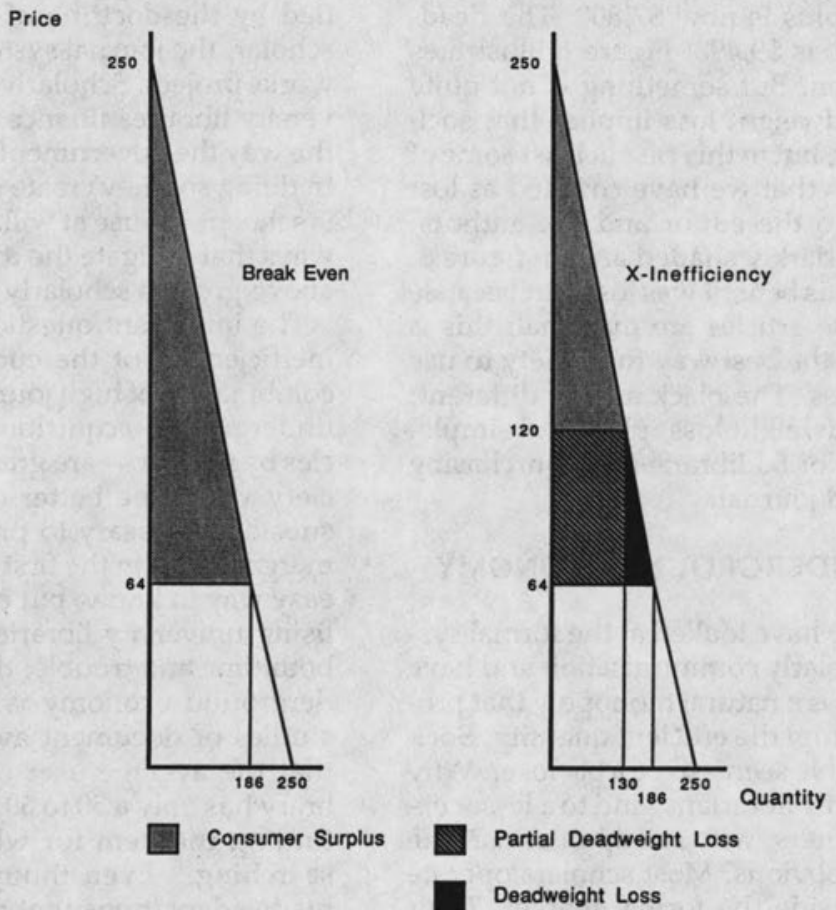

FIGURE 6

$\mathrm{X}$-Inefficiency 
academic prestige; the editor can publish more papers by friends, former students, or simply those who share his or her academic views. The result is larger, higherpriced journal with a smaller distribution. ${ }^{16}$ To the established scholars who manage much of the journal system, it is the journal's role as bestower of academic recognition that is paramount, not its role as distributor of scholarly information. For the latter, the established scholar relies on other means: conferences, preprints, and a network of colleagues.

To illustrate, consider the library market for our sample journal. We showed that the break-even point was at a price of $\$ 64$ where 186 subscriptions would be sold. There was no producer surplus and the consumer surplus was $\$ 17,298$. We will use these figures as a base point. Consider now that rather than charging $\$ 64$ the editor decides to print more pages, and to do so raises the price to $\$ 120$. This change in turn leads to 130 subscriptions. Again there is no producer surplus and the consumer surplus is now $\$ 7,800$. The deadweight loss is $\$ 9,498$. Figure 6 illustrates the situation. But something is not quite right. Deadweight loss implies that society has lost, but in this case at least some of the surplus that we have counted as lost has gone to the editor and the authors. This is the darkly shaded area in figure 6 . Not all of this benefit was lost, but because some of the articles are marginal, this is clearly not the best way for society to use its resources. The black area is different; this is deadweight loss, plain and simple, as a result of 56 libraries not purchasing the inflated journal.

\section{THE UNDERGROUND ECONOMY}

So far we have looked at the formal system of scholarly communication and have seen that it is a natural monopoly that produces far from the efficient quantity. Society as a whole seems to be a big loser. Why then is it only librarians, and to a lesser extent publishers, who are up in arms? The answer is obvious. Most scholars operate largely outside the formal market. Their transactions are underground; that is, scholars rely on personal networks, the in- visible college, to provide much of the information they need. This network has a different set of demand and production functions, and different prices are faced by the individuals in it. For scholars, subscriptions are only one means of adding journal articles to their personal collections. Often they receive preprints or reprints from colleagues. They can always go to their local library and make a copy of the required article, or more likely, they can send a graduate student. It is important to note that in both of these cases the prices faced by the scholar are different from those of subscribing to the journal. The price paid by the scholar is the time spent writing for the reprint or going to the library to search out the article and a few nickels for the photocopier.

The only costs the scholar faces are marginal costs. The up-front costs are not considered. Copyright, the mechanism that is meant to provide the publisher a return on investment to cover first-copy costs, is ignored. Copying practices have been justified by the doctrine of fair use. For the scholar, the journal system is like a public works project. Scholarly societies and university libraries finance the system much the way the government finances bridges. In doing so, they create a public good that is scholars' to use at will. Scholars work in ways that mitigate the dysfunctions of the above-ground scholarly journal market.

The important question is whether the inefficiencies of the current system-the combination of high journal prices and the underground acquisition of journal articles by scholars-are great enough that society would be better off providing the subsidy necessary to price the journal at marginal cost in the first place. There is no easy way to know, but clearly the costs of using university libraries can be great in both time and trouble; this part of the underground economy is expensive. Most studies of document availability indicate that the average user of an academic library has only a 50 to 60 percent chance of finding the item for which he or she is searching. ${ }^{17}$ Even though scholars have made adaptations that may help them in using it, the scholarly journal system as it exists today is far from efficient. 
"What is important to note from these examples is that it is the goals of the publisher and the way in which the price discrimination is applied that should concern us, not simply the fact of price discrimination."

\section{WILL ELECTRONIC SYSTEMS HELP?}

Our understanding of the economics of the scholarly journal is important when we look toward the future, for there seems to be a common assumption among librarians that the advent of electronic scholarly communication will solve the scholarly journal problem. John Lubans, Jr., is typical when he writes:

In my simple thesis, electronic journals mean that libraries would no longer pay an up-front subscription cost: we would pay as we use the information in publishers' data banks. Considering the cost of computer inputting and storage, it is unlikely that publishers would maintain extensive back files or "inventories" ... Furthermore, publishers might even be motivated to "publish" only genuinely new information and reject that which does not make an obvious contribution. ${ }^{18}$

After contemplating his vision, however, Lubans comes to the conclusion that there will be few gains. "Ultimately, electronic publishing may enable us to make gains in space, but not in budgets; publishers will not give up earnings regardless of how many fewer 'pages' they may 'publish' in some giant computer."'19 While the pipe dream of the great database in the sky and the cynical view of the forever exploited are easy answers, they both ignore the fundamental economics of the distribution of scholarship.

What can we say about the economics of electronic information? To begin with, online systems, at least as they are currently conceived, will have a cost structure similar to that of scholarly journals. The upfront fixed costs to do the editorial work and promotion will remain but are likely to decrease as authors provide copy in machine-readable forms. In addition, there are fixed costs of maintaining the distribution system, the computer, and the communication network. The variable costs associated with the production of each unit of output will likely be less than the printing and distribution of a journal issue today. At most, the cost will be a few seconds of central processing unit (CPU) time and communication costs. Like scholarly journals, online information systems will be natural monopolies. The only way that a private firm will be able to exist in this environment will be to charge prices well above the efficient price and thus limit access to the few who are willing to pay a great deal. There may, however, be opportunities to improve the situation. As editorial costs fall, the amount of subsidy required to produce at the efficient quantity also falls. More importantly, universities already possess large computers and support communications networks. Such support constitutes an easy and effective subsidy.

The expectations of users of electronic systems will also change; scholars will see only the small marginal cost, not the upfront cost. They may not understand why online access to commercial information is expensive. In an electronic environment the marginal cost of distributing scholarly information may approach zero, and scholars might expect that the access to this information should be provided as a public good. They will want access to the whole universe of knowledge through their personal computers.

Another predictable effect of digital information will be that the underground information economy will be even more widespread than it is today. As Theodor Nelson, the father of hypertext, has said:

Once material goes out to the user, there is no telling what becomes of it. The user may read it on a screen, print it out or save it on a disk, and there is no reasonable way of preventing this or telling that he has done so. Thus we must live with the fact that there is no controlling the output, or its use, once it exits the wire. ${ }^{20}$

This prospect frightens publishers, and their fears may be justified. In the past, copyright has provided exclusive rights that have allowed publishers to recover 
their up-front costs. When copying becomes impossible to stop, copyright will be less important a protection for intellectual property than restricted access. But can any reasonable restriction be effective? After all, the point is to sell information, not to horde it. The ease with which digital information of all types can be reproduced suggests that if high prices for information continue in the legitimate marketplace, an underground electronic information economy will flourish.

Another scenario suggests that publishers and libraries may not be necessary. A scholar-to-scholar network that combines electronic mail and bulletin boards may create a wired version of the invisible college. In the extreme case, each scholar becomes his or her own publisher; they pay the cost of putting their own material onto the network and they receive royalties directly each time their material is used. The costs of computers and communications will still need to be paid, but as noted, subsidy mechanisms already exist. Although there is concern about refereeing in such a system, it is easy to imagine a system that would incorporate peer review.

Electronic media may lower production prices and to some extent cut publishers and libraries out of the loop, but the real advantage of electronic systems will be to allow institutions to create marginal prices for their members by subsidizing information services internally. In its electronic from, scholarly publishing remains a natural monopoly, and especially when commercial firms are the producers, pricing and distribution patterns will be similar to those of the scholarly journal. What changes with electronic information is that subsidy mechanisms are much easier to implement. A library, if it chooses, will be able to redistribute the information within its parent organization at the marginal price. The trick for libraries has always been to find the means to acquire expensive information and to make it widely available to its users at a low cost in both time, trouble, and dollars. In a paper world this was a difficult, if not impossible, task. In an electronic world the task is much easier to imagine. It will require the development of a technical infrastructure, the negotiation of redistribution arrangements with publishers, and the development of internal pricing structures and accounting systems; while difficult, all of these requirements are possible.

\section{CHOICES}

As is often the case, understanding the economics of a problem does not provide easy answers; rather, it clarifies the alternatives. There will still be conflicting interests and different beneficiaries of different policies. But at least we have a better idea of what the choices are and where the benefits fall. As we have seen, the distribution of scholarship is a natural monopoly. This means that unless there is a subsidy, the system will not work efficiently. There are then two important questions. First, is information distribution important enough to justify the subsidy? And if it is, how and to whom is the subsidy provided? If we answer the first question affirmatively, we will confront political battles that can only be won if we have carefully considered our answer to the second question.

Even if libraries make considerable changes in their demand for scholarly journals, which is unlikely in the short term, the production function of scholarly information will mean that the market structure and prices will remain much as they are now. The most efficient solution is to provide subsidies for the distribution of scholarship, but without fundamental changes in government information policy this will not happen. In a paper system there are ways to reduce the cost of distributing information within an organization. We can make libraries easier to use or provide document delivery and selective dissemination of information services. But because print is by nature cumbersome to copy, and because copyright issues are still largely unsettled, the possibilities are limited.

Electronic information will provide greater opportunities for organizations to redistribute information internally. Subsidy mechanisms will be much easier to implement so that surplus inside the organization can be maximized. The acquisitions of funds for subsidizing information 
services-the tax problem-will remain a difficult task. The argument that needs to be made is one of increasing institutional surplus through a subsidy to information infrastructure and services. The importance of the natural monopoly model of scholarly communication is that it makes the benefits of such an investment clear. If we fail to make this case, we may end up perpetuating the inefficiencies of the scholarly journal.

\section{REFERENCES AND NOTES}

1. For a sampling of library opinion see Richard DeGennaro, "Escalating Journal Prices: Time to Fight Back," American Libraries 8:69-74 (Feb. 1977); Richard M. Dougherty and Brenda L. Johnson, "Periodical Price Escalation: A Library Response," Library Journal 113:27-29 (May 15, 1988); John Lubans, Jr., "Scholars and Serials," American Libraries 18:180 (Mar. 1987); and Herbert S. White, "Differential Pricing," Library Jourmal 111:170-71 (Sept. 1, 1986). For a publisher's viewpoint see John Tagler, "Counterpoint: A Publisher's Perspective," American Libraries 19:767 (Oct. 1988).

2. The best information on library behavior in regard to journal selection and cancelation is provided in two studies by Herbert S. White: "Publishers, Libraries, and Costs of Journal Subscriptions in Times of Funding Retrenchment," Library Quarterly 46:359-77 (Oct. 1976) and "Factors in the Decision by Individuals and Libraries to Place or Cancel Subscriptions to Scholarly and Research Journals," Library Quarterly 50:287-309 (July 1980). See also Richard M. Dougherty and Nancy E. Barr, "Paying the Piper: ARL Libraries Respond to Skyrocketing Journal Subscription Prices," Journal of Academic Librarianship 14:4-9 (Mar. 1988); and Ann Okerson, "Of Making Many Books There Is No End: Report on Serials Prices for the Association of Research Libraries," in Report of the ARL Serials Project, Washington, D.C.: Association of Research Libraries, 1989, especially chapter two, "Description of the Problem for ARL Libraries," p.7-22.

3. Edward A. Dyl, "A Note on Price Discrimination by Academic Journals," Library Quarterly 53:161 (Apr. 1983).

4. Malcolm Getz, "How Journals Are Priced," Bottom Line: A Financial Magazine for Librarians 2:39 (Dec. 1988).

5. Ibid.

6. Sandra R. Moline, "The Influence of Subject, Publisher, Type, and Quantity Published on Journal Prices," Journal of Academic Librarianship 15:12-18 (Mar. 1989).

7. Dyl makes an interesting point in this regard. In both the library and the personal markets, it is the faculty member who makes the purchasing decisions. The difference is that in the personal market the faculty member is using his or her own money. In the library market, the money belongs to someone else. Given this situation the differences in elasticity between the two markets is understandable. See Dyl, "A Note on Price Discrimination," p.162. White's study provides some empirical support for this contention. See White, "Factors in the Decision by Individuals and Libraries," p.298-300.

8. In fact, subsidy is not the only means of providing production at an efficient quantity. Taxes or government regulations are alternatives, but because the scholarly journal market is international and because of concerns for academic freedom, these solutions are probably neither practical nor desirable.

9. It is important to note that a profit, as we normally think of it, as return of investment, is included in a firm's cost of doing business. Economic profit is profit above and beyond profit in the normal sense.

10. In an interesting study of the mineralogy and related literature, journals with high bibliometric ratings (based on citation counts) received more papers that were grant supported. These journals tended to be published by societies, to have higher circulation, and to have lower prices. Perhaps this is an indication that this form of subsidy could be effective. See Paul H. Ribbe, "Assessment of Prestige and Price of Professional Publications," American Mineralogist 73:449-69 (May/June 1988).

11. Although this example is made up, it is not beyond belief. The individual (member) subscription price of Physical Review Letters in 1988 was $\$ 70$; the institutional (nonmember) price was $\$ 625$. For Tetrahedron the 1988 special price for individuals was DM 278; for institutions the price was DM 4,700. Sex Roles: A Journal of Research cost individuals $\$ 25$ in 1988; institutions faced a subscription price of $\$ 168.50$.

12. A recent study, commissioned by the Association of Research Libraries, of costs and prices of several major commercial scholarly publishing firms indicates a strong tendency toward profit- 
maximizing pricing and implies that the firms have considerable monopoly power. See Economic Consulting Services, Inc., "A Study of Trends in Average Prices and Costs of Certain Serials Over Time," in Report of the ARL Serials Project, Washington, D.C.: Association of Research Libraries, 1989. Henry Barschall's study of physics journals also provides supporting evidence: Henry H. Barschall, "The Cost-Effectiveness of Physics Journals," Physics Today 41:56-59 (July 1988).

13. In fact, Michael Koenig has argued that dual pricing allows subscription prices lower than would otherwise be the case. See Michael E. D. Koenig, "Serials Dual Pricing: The Librarians' Hobgoblin," Serials Librarian 8:25-28 (Spring 1984).

14. Dyl, "A Note on Price Discrimination," see table 1: "Pricing Policies of Academic Journals," p.164.

15. Patrick Joyce and Thomas E. Merz, "Price Discrimination in Academic Journals," Library Quarterly 55:273-83 (July 1985). See table 2: "Mean Percentage Markup, 1974" p.278, and table 3: "Mean Percentage Markup, 1984" p.279.

16. Moline's finding that categories of journals that had higher costs per thousand characters printed also printed more pages supports this theory. See Moline, "The Influence of Subject, Publisher, Type, and Quantity Published on Journal Prices," p.18.

17. See, for example, Ann C. Ciliberti and others, "Materials Availability: A Study of Academic Library Performance," College \& Research Libraries 48:513-27 (Nov. 1987); Rita Holt Smith and Warner Grande, "User and Library Failures in an Undergraduate Library," College \& Research Libraries 39:467-73 (Nov. 1978); or Jo Bell Whitlach and Karen Kieffer, "Service at San Jose State University: Survey of Document Availability," Journal of Academic Librarianship 4:196-99 (July 1978).

18. Lubans, "Scholars and Serials," p.180.

19. Ibid., p.181.

20. Theodor H. Nelson, "A Vision of the Future: Too Important to Be Left to Technicians," Publishers Weekly 226:51 (Nov. 23, 1984).

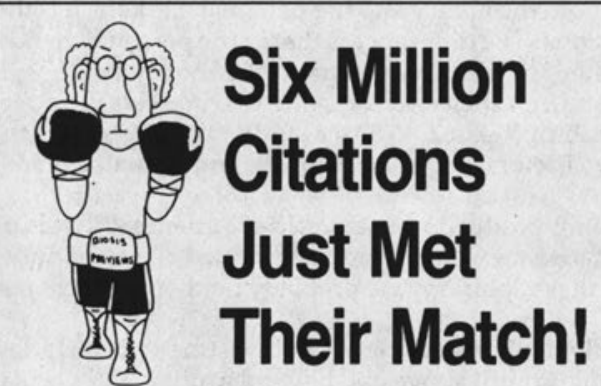

Match wits with the BIOSIS Previews* database. The new 1989 edition of the BIOSIS Previews Search Guide is the key to quick and effective searching of the BIOSIS Previews database. Here's what you get:

- Almost 1,000 new words in the Master Index-nearly 17,000 entries. The Master Index in the BIOSIS Previews Search Guide will lead you to all the words you need to know when searching for life science literature.

- The Concept Code Section has been broken down into three parts so you can more readily locate the information you need. These sections help you to match keywords and subjects with approximately 600 indexing terms.

- The Biosystematic Code Section enables you to match taxonomic names with over 700 alpha-numeric codes assigned by our indexers.

- New for this year is a Search System Information Section which includes vendor specific information on how to search the database.

- The enhanced Searching Fundamentals Section shows you how to make your search strategies more effective and provides you with even more moneysaving tips.

The new BIOSIS Previews Search Guide is a perfect match for searching the BIOSIS Previews database. And this year it's better than ever. Why not start cutting down the time you spend online? Order your copy now! Just $\$ 95.00$ for this invaluable reference tool.

Place your order today! Contact BIOSIS, Customer Services Section, 2100 Arch Street, Dept. CRL1189MM, Philadelphia, PA 19103-1399 USA. Telephone (215) 587-4800 woridwide; toll free 1-800-523-4806 (USA except PA); Telex 831739; BIOSIS Fax (215) 587-2016.

BIOSIS Previews is a registered trademark of BIOSIS. BIOSIS is a registered trademark of Biological Abstracts inc. 


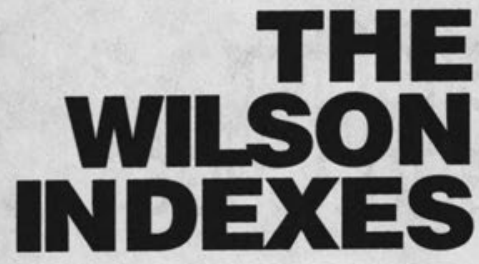

B O O K I N D E X E S

When You Need an Answer Fast and it Has to be Right

Offering broad coverage, unparalleled accuracy, and unmatched currency, the Wilson Indexes are your key to important literature in business and law, science and technology, art, education, the humanities, the social sciences, and general reference.

Now you can search these renowned indexes in print, online, on CD-ROM, and with patron-accessible software.

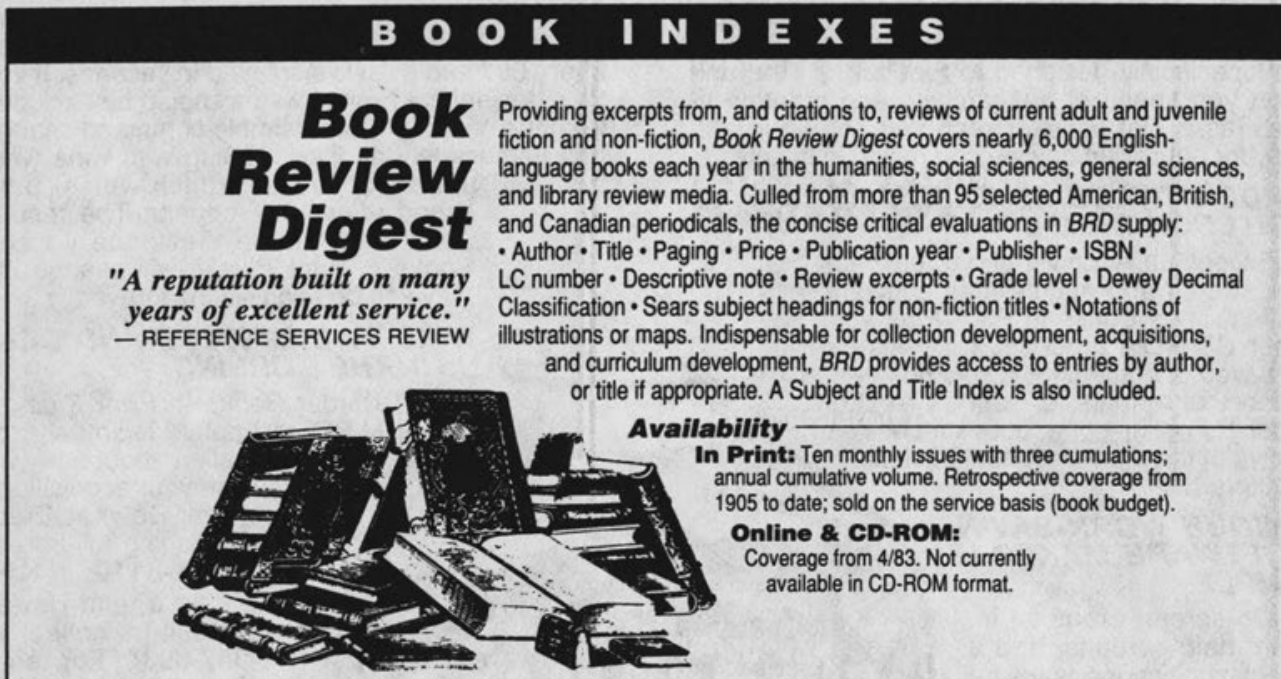

\section{Cumulative Book Index}

Compiled by professional librarians, this single-alphabet subject-author, and title index provides a complete, permanent record of the approximately 50,000 Englishlanguage books published each year around the world. Nearly half of the records in Cumulative Book Index are based on an examination of the actual book; the remainder are derived from U.S. and British MARC records and other reliable sources. Following AACR2 guidelines for descriptive cataloging and the Library of Congress Subject Headings, each main entry in CBI may include: • Author or Editor's full name $\cdot$ Title $\cdot$ Subtitle $\cdot$ lllustrator $\cdot$ Translator $\cdot$ Compiler $\cdot$ Edition $\cdot$ Series note - Size if other than standard - Paging • Illustrations • Binding if other than cloth - Price • Publication date • Publisher • Distributor • ISBN and LC numbers.

\section{Availability}

In Print: Eleven monthly issues cumulated quarterly; annual cumulative volume. Retrospective coverage from 1928 to date; sold on the service basis (book budget).

Online \& CD-ROM: Coverage from 1/82. CD-ROM annual subscription \$1,295.
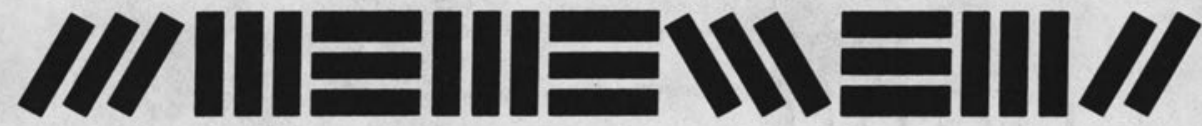

THE

H.w. WILSON COMPANY 


\section{Fast, effective relief for your acquisitions headaches.}

Unlike some CD-ROM products, which are nothing more than electronic vendors' catalogs, Books In Print Plus $\mathrm{TM}$ is an important acquisitions tool specifically designed to reduce the time and effort you spend on researching and ordering titles. Tasks that used to keep you and your staft busy for hours can now be completed in minutes.
Custom search through the database by combining any or all of up to 18 search criteria. For example, search for all titles dealing with wine published after 1987 and a list is displayed in seconds. If you then decide that French wines should be excluded from the search, make a simple command change and immediately all titles dealing with wine (with the exception of French wines) published after 1987 appear. The results are so incredible that once you try Books In Print Plus, it will change the way you do acquisitions forever.

\section{TAKE TWO MINUTES AND CALL} US IN THE MORNING.

To order Books In Print Plus for the IBM PC or Apple ${ }^{\oplus}$ Macintosh ${ }^{\oplus}$, or for more information about how you can streamline your acquisitions process, call Bowker Electronic Publishing toll-free at 1-800-521-8110. In New York, Alaska, and Hawail please call us collect at 212-337-6934. For technical assistance call 1 . 800-323-3288. You'll be feeling better in no time.

time getting up and running with Books In Print Plus.

On-screen prompts, instant help screens, and a special novice mode insure special novice mon't waste any
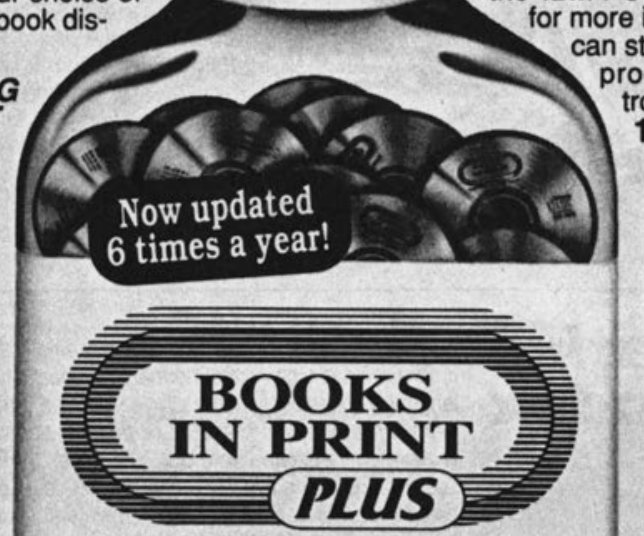

FAST, EFFECTIVE RELIEF FOR ACQUISITIONS HEADACHES.

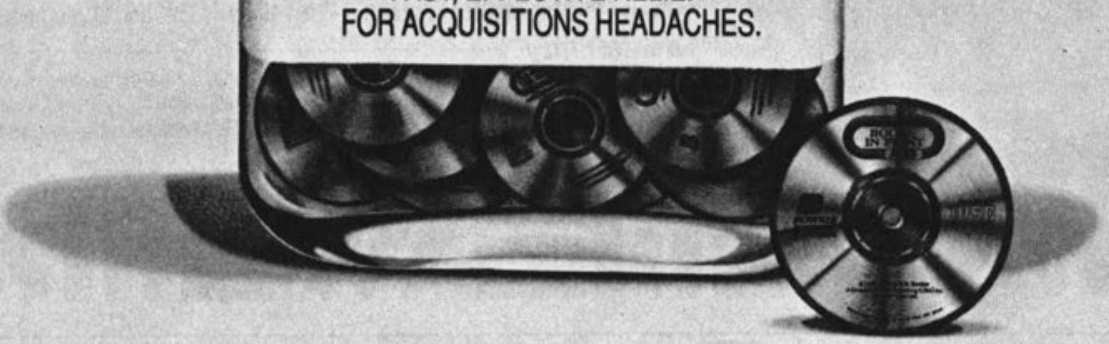

- Electronic ordering software furnished by distributors.

\section{$B O W K E R$ ELE C T R O N I C P U B L I S H I N G}

